\title{
Multidrug and Toxin Extrusion Protein 1
}

National Cancer Institute

\section{Source}

National Cancer Institute. Multidrug and Toxin Extrusion Protein 1. NCI Thesaurus. Code C113566.

Multidrug and toxin extrusion protein 1 (570 aa, $62 \mathrm{kDa}$ ) is encoded by the human SLC47A1 gene. This protein plays a role in transport of cationic drugs across membranes. 